\title{
Student mathematical activity as a springboard to developing teacher didactisation practices
}

\author{
Authors: \\ Piera Biccard ${ }^{1}$ \\ Dirk Wessels ${ }^{1}$ \\ Affiliation: \\ ${ }^{1}$ Department of Curriculum \\ Studies, Research Unit for \\ Mathematics Education, \\ Stellenbosch University, \\ South Africa

\section{Correspondence to:} \\ Piera Biccard \\ Email: \\ biccardwps@gmail.com \\ Postal address: \\ Private Bag X1, Matieland \\ 7602 , South Africa

\section{Dates:} \\ Received: 31 Mar. 2015 \\ Accepted: 01 Sept. 2015 \\ Published: 07 Dec. 2015 \\ How to cite this article: \\ Biccard, P., \& Wessels, D. \\ (2015). Student mathematical \\ activity as a springboard \\ to developing teacher \\ didactisation practices. \\ Pythagoras, 36(2), Art. \\ \#294, 9 pages. http://dx.doi. \\ org/10.4102/pythagoras. \\ v36i2.294

\section{Copyright:} \\ (C) 2015. The Authors. \\ Licensee: AOSIS \\ OpenJournals. This work is \\ licensed under the Creative \\ Commons Attribution \\ License.
}

Read online:

Scan this QR code with your smart phone or mobile device to read online.
This article is part of a larger study on teacher development. The main study investigated teacher development within primary school Mathematics teachers' classrooms to determine if teaching practices could be enhanced through a didactisation-based programme. It sought to develop teachers within their own environments and classrooms. Design research (both designing the conditions for change and studying the results of those conditions) enabled the researchers to design a programme that was congruent with teachers' own needs and experiences. The programme ran for a period of a year with regular contact between the teachers and the researcher conducting the programme (the first author). The programme set out nine didactisation practices: active students, differentiation, mathematisation, vertically aligned lessons, accessing student thinking and ideas, probing student thinking and ideas, connecting student ideas, assessing students and reflecting on practice. One practice, student activity, is the focus of this article. It was found that by initiating discussion and cognitive conflict in teachers by using modelling problems, and further allowing teachers to observe pupils working in groups with modelling problems, teachers were starting to incorporate the didactisation practices within their own classrooms. This article documents specifically the fundamental role of student mathematical activity and the importance of improving student mathematical experiences, both for teacher development and for student mathematical learning. The study may be valuable in structuring and planning further effective teacher development programmes.

\section{Introduction}

Mathematics teaching and learning is a priority in many countries around the world. South Africa is no different and the latest national assessments indicate mathematics education in South Africa is in dire straits, with the Grade 9 average for Mathematics being 14\% (Department of Basic Education, 2013). Although the situation is complex, and many factors contribute to this, Mathematics teachers need to be developed so that a change in performance can be realised. In this article, a teacher development programme is described that formed part of a larger study on didactisation practices (Biccard, 2013). The focus of this professional development programme was the didactisation practices of primary school Mathematics teachers (Grade 5 and Grade 6). These practices were filtered from Treffers's (1987) term 'didactisation' and Wilson and Heid's (2010) 'mathematical work of teaching'. Design research allowed an integrated, iterative research design between the researcher and five teacher participants.

Teacher change in the study was catalysed through teacher exposure to mathematical modelling tasks and being involved in in-depth reflective discussions. The focus of this article is on how student activity (as one of the didactisation practices) was optimised by teachers and how this effected a change within the classroom culture and within teachers' own development of didactisation practices. Traditional mathematics classrooms are characterised by low studentinitiated mathematical activity. Lessons often follow a predictable teacher explanation session followed by routine procedures completed by students. Mathematics presented to students in these classrooms is largely deductive: a general rule is taught upfront and practised by means of various examples in what Freudenthal (1991) describes as an 'anti-didactical inversion'. There is a need to create a more constructive type of classroom, where students are active participants in their own mathematical learning: classrooms where student ideas are stimulated, and teacherstudent as well as student-student discussions are rich ground for mathematical thinking. We need classrooms where the type of mathematical thinking required of students is more inductive, more personal and more meaningful. The programme envisaged teachers encouraging students to become more mathematically active in their lessons. How, and to what extent, this could happen was an important question in the design of the programme. The programme sought to encourage teachers to incorporate more opportunities for their students to: think and talk about what they were doing, arrange the learning process and be involved in constructing their own meaning. 
The effect of increasing student mathematical activity in mathematics classrooms needed to be gauged and documented. Mathematical activity where students are exploring, conjecturing and making connections is more difficult to incorporate in lessons than simply solving mechanical problems. The effect of broadening student mathematical activity experiences on both the nature of student learning and teacher development needed to be studied. It was hoped that the classrooms would change from being based on teacher explanations only, to being more learner centred and more problem centred. The spin-off of making classrooms more learner participatory is that the role of both the students and the teachers had to be reconsidered. It was through mediating these changes that teachers would reflect on and develop their practices. A number of questions are scrutinised in this article. Can teachers change the level of student mathematical activity in their classrooms? What is the nature of this change? How does this affect the nature of mathematical learning in these classrooms? How would an increase in student activity assist teachers in developing other didactisation practices? The level, type and nature of student activity is the focus of this article.

\section{Didactisation and mathematical work of teaching framework}

Realistic mathematics education (RME) provides a basis for the theoretical framework of the article. RME is a teaching and learning theory that is underpinned by the work of Freudenthal, Treffers, Gravemeijer and others. The principles of guided re-invention, self-developed models and didactical phenomenology (Gravemeijer, 1994) were incorporated into the study. At the heart of RME theory is the concept of mathematisation and how important it is for students to re-invent mathematisation. Treffers (1987) defines didactisation as the essence of didactical action which makes mathematisation possible' (p. 58). Furthermore, Treffers outlined four components of didactisation from a RME perspective. They are:

- Active students - what mathematics are the students working through or dealing with? Is it procedures only or do they have to engage with the material and make sense of it? Are there different ways of approaching the problem or are they simply repeating a procedure? Is there a need to discuss what they are working on? Is there more to discuss than only the solution?

- Differentiation - does the problem lend itself to a variety of approaches? Can students with different understanding deal with and access the problem?

- Mathematisation - this is at the heart of a mathematics lesson. What mathematics are students learning and how are they learning it? Can they bridge from a contextual problem to mathematics? How can they shorten their methods by using more elegant solution paths?

- Vertically aligned lessons - this refers to the teaching and learning trajectory a teacher has set for students, whether it is a short-term trajectory through a particular section of work or a long-term yearly trajectory. In terms of mathematics, a progressive mathematisation is sought where there is a building of mathematical structures or a deeper, more complex understanding of surface features of a problem. Essentially, does the teaching trajectory allow for scaffolding or reflecting on student informal ideas to more formal mathematics?

These components formed an integral part of the didactisation practices envisaged for teacher development in the study. They encapsulate essential features of mathematics classrooms where student involvement and student understanding is central. Understanding mathematisation is fundamental to theorising about teacher actions and teacher decision-making that may lead to significant learning in a mathematics classroom.

Freudenthal (1993, p. 72) formulates a description of mathematisation as turning 'mathematically underdeveloped matter into more distinct mathematics' while he stipulates that mathematisation is translated into 'reinventing' (Freudenthal, 1991, p. 67). Mathematisation is therefore closely tied to student activity and student thinking and raising student understanding of mathematics to more abstract levels. Gravemeijer (1994) sets out four level-raising features of mathematisation:

- Generalising - looking for analogies classifying and structuring.

- Certainty - reflecting, justifying, proving (using a systematic approach, elaborating and testing conjectures).

- Exactness - modelling, symbolising and defining.

- Brevity - symbolising and schematising (developing standard procedures and notations) (p. 82).

The level of thinking in mathematics is raised from looking for analogies and structuring to reflecting and proving and finally to symbolising and schematising. This level raising, according to Gravemeijer specifically involves generalising and formalising. Formalising embraces modelling, symbolising, schematising and defining while generalising refers to a 'construction of connections' and not an application of general knowledge (Gravemeijer, 1994, p. 83).

Teacher development programmes within mathematics education would benefit from keeping these descriptions close to their aims and focus. Teacher development needs to be centred on student mathematising and how teachers and students together can raise the level of thinking through solving contextual problems. Level raising in mathematics classrooms presupposes mathematical activity on the part of the students. Teacher development should consider teachers and students as active reflective participants within their own classrooms as suggested by Fosnot, Dolk, Zolkower, Hersch and Seignoret (2006):

We engaged in-service teachers in experiences that involved action, reflection and conversation within the context or learning/teaching. We took the perspective that teachers need to construct new gestalts, new visions of mathematics 
teaching and learning. To do this they need to be learners in an environment where mathematics is taught as mathematising, where learning is seen as constructing in terms of professional development of teachers. (p. 7)

To further understand and guide the actions and decisions of Mathematics teachers, a framework that focused on the work of teachers was also needed to understand the very complex, messy domain of mathematics classrooms. Wilson and Heid (2010) provided a proficiency framework to describe teacher knowledge, actions and skills. As part of the framework, they described the mathematical work of teaching (p. 6). This aspect of their framework reminds us that teaching comprises essential components that can be developed in all teachers. These components serve as good starting points in teacher development programmes since they focus on specific teacher actions and decisions-making ideas. The mathematical work of teaching framework comprised the following teacher actions:

- probe mathematical ideas

- access and understand the mathematical thinking of learners

- know and use the curriculum

- assess the mathematical knowledge of learners

- reflect on the mathematics of practice.

A proficiency framework was preferred to a knowledge-only framework since it allowed closer access to identifying and understanding authentic Mathematics teacher decisions that translate into actions in classrooms. The mathematical work of teaching framework made it possible for the researcher to prepare for the practical aspect of the teacher development programme and to bridge the day-to-day teacher actions with the theoretical aspects of teaching. On reflection of the above components, Treffers's vertically aligned lessons and Wilson and Heid's 'know and use the curriculum' were considered to be of a similar nature so that they are grouped together. Furthermore a teacher's proficiency or competence to connect student ideas and thinking is vital to effective mathematics teaching and learning so it was included as a didactisation practice (Biccard, 2013). This resulted in nine didactisation practices drawn from Treffers and Wilson and Heid. Those from Treffers relate to the what of effective mathematics teaching and those from Wilson and Heid relate to the how of effective teaching (Biccard, 2013, p. 49). The nine didactisation practices incorporated in the main study are:

- student activity

- differentiation

- mathematisation

- vertically aligned lessons

- access student thinking and ideas

- probe student thinking and ideas

- connect student ideas

- assess student thinking

- reflect on practice.

As the professional development programme progressed, it was found that an improvement in student activity was the first to develop. Furthermore, it was found that other didactisation practices are stimulated by, and could further be developed through, meaningful student activity and teacher reflection on this activity. This resulted in a hierarchy of didactisation practices with student activity at its base (Biccard, 2013, p. 278; reproduced as Figure 2). Meaningful teacher development that results in effective classroom implementation of reform ideas requires firstly that students are mathematically active.

\section{Active students as a theoretical construct in teaching}

Starting with a basic definition of activity allows one to place it within the mathematics learning domain. According to the Concise Oxford English Dictionary activity includes the definition: 'the condition in which things are happening or being done'.

This means that activity can be graded by the conditions under which the activity takes place. To extend this would mean that the activity needs to be judiciously placed and incorporated by the teacher within a lesson to maximise its effect in learning. It would also mean that the conditions in a lesson are guided by a teacher's decisions, actions, beliefs and aims. To change the conditions under which an activity takes place, the teacher's decisions before and during that lesson would need to be examined and developed. Further reflection after a lesson would refine these ideas. In a traditional setting mathematical learning takes place under conditions where teachers explain set methods and students repeat these procedures. However in problem-centred environments the teachers present students with contextual problems. Through interacting with the problem and socially developing meaning with each other, students construct mathematical concepts. The conditions under which teaching and learning take place in these settings is different and so for teachers and students to adapt to a reformed setting is significant.

Brousseau (1997) defines the term devolution of a problem as the students accepting responsibility for solving a problem (p. 30). He explains that students have to adapt to this new role or milieu which constitutes an adidactical situation. A meaningful learning situation is one in which the conditions in which things happen are different from conditions where students only answer drill-type questions. Hmelo-Silver (2004) confirms the role of responsibility in making students more active in lessons. In traditional classrooms, teachers assume almost all the responsibility of the mathematical work to be done; their students are largely passive observers of their teacher taking part in all the 'action'. Handing over the activity of doing mathematics to the students implies handing over responsibility to the students. In traditional classrooms teachers only hand over repeating the procedure they have just shown, but the responsibility of coming up with the mathematical procedure or method is the teacher's. The traditional teacher believes that students are not able to come up with significant ways of thinking or working 
mathematically; they have to be shown. Allocating the responsibility of thinking mathematically to the students may be accompanied by feelings of loss of control by the teacher and a feeling of being overwhelmed by the sense of responsibility by the students. This is in line with Stigler and Hiebert's (1998) formulation that teachers do not want students to struggle with mathematics; teachers see their role as having to make things as easy as possible for students (p. 3). The roles of both the teacher and the students are modified under these changing conditions. When teachers learn to trust the mathematical thinking of their students and to value the meaningful learning that takes place through problem-solving, teachers will change their goals for mathematics lessons. When teachers place students in mathematically active roles in their classrooms, not only is mathematical thinking enhanced but teachers develop as a result too.

Skemp (1986) explains that traditional mathematics teaching is dominated by verbal-algebraic imagery and not visual imagery since the verbal-algebraic is easier to communicate and is analytical, sequential and logical while visual imagery is integrative, simultaneous and intuitive (p. 104). The reliance on verbal definitions affects students' meaningful learning in traditional classrooms since, 'concepts of a higher order than those which people already have cannot be communicated to them by a definition' (Skemp, 1986, p. 25). However, traditional teaching that is definition based without the supporting student interaction and activity is still a major focus in mathematics classrooms today. Student learning and a change of teacher practices may be enhanced by moving from a verbal and static approach towards a more dynamic and active approach.

Treffers (1987) advocated that students also work interactively with each other. He linked the role of meaningful student activity to mathematisation (p. 249). He maintained that interactive learning would allow students to either shorten their own methods or to become aware of the advantages and disadvantages of their own ideas and methods. This vertical mathematisation is ultimately the goal of mathematics teaching and learning. Biccard (2013) analysed Pegg and Tall's (2005) fundamental cycle of concept construction and found that in the comparison of concept construction by several authors, the term 'process' was critical in vertical mathematisation. The term process was accepted as performing a composite cognitive activity (Biccard, 2013, p. 59); when students reflected on the effect of their activities or actions, this assisted in building concepts or procepts (Pegg \& Tall, 2005, p. 473). Furthermore, Freudenthal's (1991) analysis of the Van Hiele levels in learning processes reminds us that the student's activities on a lower level become the objects of analysis on a higher level (p. 98).

It would therefore appear that part of the conditions under which student activity becomes meaningful in mathematical learning is that of reflecting on their activity and the effect of their actions. Classrooms that are teacher-directed and teacher-presented allow very little student discussion or deep reflection. Vygotsky (1978) specifically forges the link between speech and action (p. 25). He proposes that speech and action are part of the same psychological function and that the more demanding the activity, the more important the role speech plays in solving the problem. Traditional classrooms that are largely silent may pose problems for students in understanding significant mathematical concepts. It also allows less insight into the mathematisation process. Students may also struggle with real-world application problems.

Lesh and Doerr (2003) describe modelling and modeleliciting activities. The tasks are rich, real-world contextbased and require groups of students to solve them. The tasks are designed so that students have to formulate a situational model of the problem as well as a generalisable model for similar situations. Lesh and Doerr explain that the models students construct are 'sharable, manipulatable, modifiable, and reusable tools for constructing, describing, predicting or controlling mathematically significant systems'. Modelling is the type of task that changes the conditions under which mathematical activity takes place. It creates an innovative learning environment where students use mathematics towards a significant end. This is also true of teacher learning through professional development programmes. Modelling tasks were used during the teacher development programme in the main study to stimulate paradigm shifts within practising teachers and to catapult teacher thinking about the nature of mathematical activities. The first step in developing teachers' didactisation practices would be to help them to understand the importance of mathematically meaningful student activities whereon they could build their didactisation proficiencies.

The professional development programme designed in this study changed the conditions under which teachers learn by presenting them with modelling problems; firstly, they solved the problems as a group and, secondly, they observed groups of students solving the same problem. This led to teachers reflecting on these activities and making different decisions for their lessons in ways that each teacher decided according to their own goals and resources. Biccard (2013, p. 291) concludes that modelling tasks became a knowledge resource for teachers. She further documents (p. 189) that modelling problems made teachers stop and consider their beliefs and orientations about mathematics teaching. Their observation of students solving modelling problems became rich ground for discussing the nature of different mathematical problems in classrooms. Other studies (Schorr \& Lesh, 2003; Stillman, 2010) have also shown that modelling tasks have a profound influence on teacher thinking and that teachers themselves experience discomfort ( $\mathrm{Ng}, 2010, \mathrm{p} .142)$ with mathematical tasks of a different nature to traditional tasks.

\section{The study \\ Participants and research design}

The study involved five primary school Mathematics teachers. They were teaching Grade 5 and Grade 6 students 
(aged 10-12 years). The five teachers volunteered to be part of the programme, which lasted about 9 months over a period of one year. Teachers were briefed on the intentions and aims of the study and they signed consent documentation. They understood that all references were anonymous and they could withdraw at any time.

The study implemented the principles of design research. This means that the researcher had to create an innovative learning environment for the teachers and study the conditions that made the environment conducive to professional development and, similarly, study the effect of the professional development. Cobb, Confrey, diSessa, Lehrer and Schauble (2003, p. 9) outlined five features of design research (also known as design experiments):

- Design experiments develop local theories about learning processes and how to support those learning processes.

- Design experiments are highly interventionist in nature.

- Design experiments are both prospective and reflective. They include a hypothetical learning trajectory as well as a retrospective analysis.

- Design experiments have an iterative design.

- The theory generated by design experiments is relatively humble.

Bakker (2004) explains that there are three phases in design research: a planning and preparation phase, a teaching experiment and a retrospective analysis. These phases are iterated so that the participants can become active members of the design and so that the researcher can make changes to the research design so that the research question can be answered or more robust analyses can be made. Design research becomes part of the learning landscape it studies and as such requires 'robust designs - ones that produce impressive results, not only under ideal conditions, but also under severe but realistic constraints' (Walker, 2006, p. 13). The 'situated nature of the retrospective analysis is the strength of the methodology' (Cobb et al., 2003) since results are presented in the context from which they emanated so that the reader can decide on their significance.

The main study included the following sequence of activities in the teacher development programme that was designed:

1. An observation of each of the volunteer teachers in practice. The didactisation principles were gauged using a variety of instruments. The pedagogy scale, use of context scale and mathematical content scale as presented by Fosnot et al. (2006, p. 10) were used, as well as categories set out by Timms (2006; see Table 3), Pea (1993; see Table 4) and Stigler and Hiebert (1998; see Figure 1). Teachers also filled in lesson reflection sheets after each session.

2. A number of contact sessions with all five teachers. During the first, fourth and seventh contact sessions, teachers worked through a modelling problem as a group. As concluded by Biccard (2013, p. 290), modelling tasks were a vehicle that developed teachers' didactisation practices by creating a scaffold for teachers to think about their own actions.

3. A 'fishbowl' session, in which teachers observed a small group of students engaging in the same modelling task the teachers had completed in the previous session.

4. Reflection session and reflection instruments at various stages.

These activities were repeated over three cycles. The researcher also provided various resources for teachers. During the third contact session teachers were given two groups of tasks: one group were of a problem-solving nature, while the other was traditional numbers-only problems. They were asked to match the number-only problem to its contextual partner problem. Teachers were then asked to discuss the nature and value of each type of problem in classrooms. Through this discussion teachers were assisted in changing traditional problems into more context-based and collaborative problems for their classrooms. Teachers also contrasted the differences between the different types of problems. It was not a requirement that teachers were to present any particular (modelling or problem-based) lesson in any of the observed lessons. It was also clear to teachers that they did not have to present any particular content during observed lessons. Teachers were to continue covering their curriculum during observed visits. Teachers were left in control of 'filtering' aspects of the professional development programme through to their own classrooms and their own practices.

Part of the programme involved resourcing teachers with the type of problems that could lend themselves to more active students in classrooms. Stigler and Hiebert (2004) present three broad ideas on how to improve classroom teaching of mathematics based on 10 years of Trends in International Mathematics and Science Study (TIMSS) video studies (p. 16). Their first suggestion is to focus on the details of teaching and not teachers. By this they mean that the focus should be on improving teaching methods, specifically the way in which the teacher and students interact. According to them, this can be 'more powerful than the curriculum materials that teachers use'. Their second suggestion is to become aware of cultural routines that are prevalent in classrooms within the same country and their third suggestion is to build a knowledge base for the teaching profession. Teachers need access to examples of alternative teaching methods that they can integrate into their own teaching (Stigler \& Hiebert, 2004, p. 12).

\section{Validity and reliability}

Since design research is qualitative in nature, the validity and reliability of the study was hinged around McKenney, Nieveen and Van den Akker's (2006) three concepts of rigour, relevance and collaboration. In terms of rigour, the main study (Biccard, 2013, p. 152) explicated a number of the McKenney et al.'s guidelines such as: setting out a conceptual framework, triangulating data sources and providing a context-rich description. For relevance the study 
took place within the natural setting of teaching and learning while collaboration took place between the researcher and teachers in that their ideas guided the sessions and resources for future sessions. Furthermore, a number of the strategies proposed by McMillan and Schumacher (2006) were included in the main study (Biccard 2013, p. 153) such as prolonged fieldwork, multi-method strategies, verbatim accounts, mechanically recorded data and a participant researcher.

\section{The results}

'Student activity' was one of nine didactisation practices that were described and explicated in the professional development programme of the main study. The didactisation principles were gauged by the researcher during observation of lessons. The first observation lesson took place before the professional development programme had started. Teachers were asked to present a typical lesson. The second and third observation lessons took place after three (and six) professional development contact sessions while the final lesson observation took place at the very end of the programme (one year after the beginning of the programme). Although the programme took place over a year, actual contact was maintained with the teachers for a period of nine months since research is not allowed at schools during the final term of the school year when pupils and teachers are preparing for the final examinations.
This article will only focus on student activity during the four lessons each of the five teachers presented. A brief summary of the student activities for each lesson is outlined in Table 1. The full versions of the lessons are described in Biccard (2013).

The main shift in the cycles of student activity in these results is from teacher doing to student doing. Another shift is from individual work to pair work or group work. The type of activities moved from single solution to multi-step solutions and multi-approach solutions. The teachers were 'devolving' the responsibility of the mathematical work to their students as the lessons progressed over the year-long period. The type of activities changed from teacher explaining ideas and concepts to students encountering and engaging with the ideas and concepts.

This change in the activity level, and the types of activities students were involved in, was gauged as summarised in Table 2.

The five lessons were observed and the activities students were involved with were recorded and are presented in Table 2. Activities such as reading, writing, organising, physical activity (cutting, constructing, etc.), anticipating and modelling were more evident in latter lesson observations. These activities raised the mathematical load the students

TABLE 1: Student activity per lesson.

\begin{tabular}{|c|c|c|c|c|}
\hline Teacher & $\begin{array}{l}\text { Baseline lesson } \\
\text { (July 2012) }\end{array}$ & $\begin{array}{l}\text { Cycle } 2 \text { lesson } \\
\text { (February 2013) }\end{array}$ & $\begin{array}{l}\text { Cycle } 3 \text { lesson } \\
\text { (April 2013) }\end{array}$ & $\begin{array}{l}\text { Final lesson } \\
\text { (June 2013) }\end{array}$ \\
\hline A & $\begin{array}{l}\text { Whole class explanation on } \\
\text { percentage increase and decrease. } \\
\text { Individual work following set } \\
\text { procedure. }\end{array}$ & $\begin{array}{l}\text { Students worked in pairs with } \\
\text { manipulatives to calculate } \\
\text { equivalent fractions. }\end{array}$ & $\begin{array}{l}\text { Students worked in pairs solving word } \\
\text { problems. }\end{array}$ & $\begin{array}{l}\text { Students worked in pairs on } \\
\text { ordering decimal numbers, then } \\
\text { reported to larger groups and finally } \\
\text { presented solutions to class. }\end{array}$ \\
\hline B & $\begin{array}{l}\text { Answered teacher's questions } \\
\text { individually. } \\
\text { Students worked silently and } \\
\text { individually on area and perimeter } \\
\text { mind maps. }\end{array}$ & $\begin{array}{l}\text { Whole class discussion on inverse } \\
\text { operations required for input/ } \\
\text { output flow diagrams. } \\
\text { Individual teacher and textbook } \\
\text { questions answered. }\end{array}$ & $\begin{array}{l}\text { Individual and group work. Building of } \\
\text { 3D shapes. } \\
\text { Feeling a 3D shape, drawing the faces } \\
\text { needed to build the shape and finally } \\
\text { building own 3D shape from toothpicks } \\
\text { and jelly sweets. }\end{array}$ & $\begin{array}{l}\text { Students worked in pairs to solve } \\
\text { one 'big' (multi-step) problem } \\
\text { involving money, profit and loss. }\end{array}$ \\
\hline G & $\begin{array}{l}\text { Teacher-led discussion on converting } \\
\text { fractions to percentages. } \\
\text { Answering teacher questions. }\end{array}$ & $\begin{array}{l}\text { Group work. Using blocks to show } \\
\text { fractional grouping (e.g. } 2 / 3 \text { of } 18 \text { ). } \\
\text { Presenting solution to rest of class. }\end{array}$ & $\begin{array}{l}\text { Factor trees. Pair-work on large sheets } \\
\text { of paper. Presenting solutions to the } \\
\text { teacher during whole class discussion. }\end{array}$ & $\begin{array}{l}\text { Modelling problem - groups solving } \\
\text { a real-life problem that needs } \\
\text { structuring and analysing. }\end{array}$ \\
\hline D Grade 6 & $\begin{array}{l}\text { Mental calculations, teacher-led } \\
\text { questions and group calculations. }\end{array}$ & $\begin{array}{l}\text { Teacher-led question and answer } \\
\text { lesson based on textbook } \\
\text { presentation of fraction wall. }\end{array}$ & $\begin{array}{l}\text { Whole class discussion based on walk } \\
\text { around the school grounds to find } \\
\text { various } 3 D \text { shapes. }\end{array}$ & Pair work on mixed word problems. \\
\hline Erade 5 & $\begin{array}{l}\text { Drill lesson on multiplying by units of } \\
10,100 \text { and } 1000 .\end{array}$ & $\begin{array}{l}\text { Teacher-led whole class discussion } \\
\text { on number patterns followed by } \\
\text { individual textbook work. }\end{array}$ & $\begin{array}{l}\text { Sharing wholes by cutting pictures of } \\
\text { pizzas and chocolates. Packing and } \\
\text { pasting fractions into books. }\end{array}$ & $\begin{array}{l}\text { Exploring 3D shapes. Looking, } \\
\text { feeling shapes. Drawing own } 3 D \text { net } \\
\text { for shapes. Comparing own net to } \\
\text { given net. }\end{array}$ \\
\hline
\end{tabular}

TABLE 2: Occurrence of student activities over five lessons.

\begin{tabular}{|c|c|c|c|c|}
\hline $\begin{array}{l}\text { Student activities that took } \\
\text { place during the lessons }\end{array}$ & $\begin{array}{l}\text { Number of lessons where } \\
\text { activity took place } \\
\text { (Baseline lessons) }\end{array}$ & $\begin{array}{l}\text { Number of lessons where } \\
\text { the activity took place } \\
\text { (Cycle } 2 \text { lessons) }\end{array}$ & $\begin{array}{l}\text { Number of lessons where } \\
\text { the activity took place } \\
\text { (Cycle } 3 \text { lessons) }\end{array}$ & $\begin{array}{l}\text { Number of lessons where } \\
\text { the activity took place } \\
\text { (Final lessons) }\end{array}$ \\
\hline Listen & 5 & 5 & 5 & 5 \\
\hline Answer questions & 4 & 5 & 5 & 4 \\
\hline Explain & 1 & 3 & 3 & 4 \\
\hline Read & 1 & 2 & 1 & 3 \\
\hline Write & 1 & 3 & 3 & 4 \\
\hline Rewrite & 2 & 2 & 0 & 1 \\
\hline Organise & 1 & 2 & 3 & 4 \\
\hline Physical activity & 0 & 2 & 3 & 1 \\
\hline Mental work & 1 & 4 & 5 & 5 \\
\hline Modelling & 0 & 0 & 0 & 1 \\
\hline
\end{tabular}


were involved in. As the students became more actively involved in constructing meaning, the role of the teachers was also gauged through the middle part of a lesson. It is titled the teacher's probing role; the three descriptive categories were taken from Timms (2006):

- The teacher as supervisor of the activity, in which the teacher answers questions or clarifies if students ask.

- The teacher as director or manager, in which the teacher initiates discussion and controls the topic, but allows or invites input.

- The teacher as facilitator, in which the teacher sets up a structure, interacts with students and students interact with each other and the materials (p. 4).

The findings are summarised in Table 3.

The teachers' roles changed as they incorporated more mathematical activity for their students and as they varied the activities that students were involved in. The change in teacher role and student role is reciprocal and is influenced by the landscape of mathematical activities in the classroom. As the conditions and responsibilities changed due to students being more active in the lessons, so the type of mathematical thinking involved changed (see Figure 1). Furthermore, teacher thinking about mathematics teaching also developed.

The use of materials also changed across the lessons. From a distributed cognition point of view (Pea in 2007, p. 13), the distribution of intelligence is across a system that comprises the individual, tools and the social context in which learning takes place. Pea (1993) also maintains that tools, artefacts and external representations mediate a problem situation. Table 4 displays the tools and materials that were incorporated into the four lessons as well as the social context of the lesson.

TABLE 3: Teacher probing of student ideas.

\begin{tabular}{|c|c|c|c|}
\hline $\begin{array}{l}\text { Teacher probing } \\
\text { role }\end{array}$ & $\begin{array}{l}\text { Teacher as } \\
\text { supervisor }\end{array}$ & $\begin{array}{c}\text { Teacher as director } \\
\text { or manager }\end{array}$ & Teacher as facilitator \\
\hline A Baseline & $x$ & - & - \\
\hline B Baseline & $x$ & - & - \\
\hline C Baseline & $x$ & - & - \\
\hline D Baseline & $x$ & - & - \\
\hline E Baseline & $x$ & - & - \\
\hline A Cycle 2 & - & - & $x$ \\
\hline B Cycle 2 & $x$ & - & - \\
\hline C Cycle 2 & - & - & $x$ \\
\hline D Cycle 2 & - & $x$ & - \\
\hline E Cycle 2 & - & $x$ & - \\
\hline A Cycle 3 & - & - & $x$ \\
\hline B Cycle 3 & - & $x$ & - \\
\hline C Cycle 3 & - & $x$ & - \\
\hline D Cycle 3 & - & $x$ & - \\
\hline E Cycle 3 & - & - & $x$ \\
\hline A Final & - & - & $x$ \\
\hline B Final & - & - & $x$ \\
\hline C Final & - & - & $x$ \\
\hline D Final & - & - & $\mathrm{x}$ \\
\hline E Final & - & - & $x$ \\
\hline
\end{tabular}

Source: Biccard, P. (2013). The didactisation practices in primary school mathematics teachers through modelling. Unpublished doctoral dissertation. Stellenbosch University, Stellenbosch, South Africa. Available from http://hdl.handle.net/10019.1/85598
Underneath each teacher's lesson description the coding of $+\mathrm{M}$ or $+\mathrm{S}$ is used to indicate if the materials $(\mathrm{M})$ or social context (S) were improved from the Baseline lesson.

As can be seen in Table 4, teachers moved from individual work to pair work and group work. Pair work was most common. It may have allowed teachers more control over the class as they ventured into changing the social context of their classrooms. Teachers also started using large sheets of paper for students to work on as well as introducing physical items for the students to use. This was necessitated by teacher planning for a wider variety of activities in their classrooms. A further look at the $+\mathrm{M}$ and $+\mathrm{S}$ coding may allow us to deduce that a change in materials seems to be accompanied by a change in social setting, but a change in the social setting does not have to be accompanied by a change to the materials used in the lesson. Another deduction could be that teachers may find it easier to change the social setting of their lessons than change the materials required to extend activity within the lesson. This may be affected by resources that are available or curriculum coverage pressures. Distributed cognition assists in understanding that abstraction as a result of reflection can be a reflection on social, mental or physical activity.

A further aspect of development within these mathematics classrooms can be dissected using Stigler and Hiebert's (1998) analysis of TIMSS video lessons where mathematical thinking can be thought of in two broad terms: inductive thinking and deductive thinking. Typical traditional lessons involve mostly deductive thinking where the teacher presents a method and students use the method on a number of similar problems while with inductive reasoning students move from solving problems to generalising and abstracting mathematical ideas from the problems. Stigler and Hiebert outline three differentiating student mathematical activities on an inductive-deductive thinking continuum: practising a routine procedure, applying procedures in new situations and inventing new procedures or analysing new situations. The 20 lessons in the main study were analysed for this article using these three constructs to understand the role of student activity in the quality of student thinking. The resulting Figure 1 highlights that student activity did improve during the professional development programme on didactisation practices and the quality of mathematical thinking moved towards more inductive type thinking.

Although lessons showed shifts along an inductivedeductive continuum, it is important to state that mathematics lessons may include a judicious mix of the two. Traditional lessons tend to be exclusively deductive in nature. It is evident in this study that teachers are trying new ways of teaching mathematics. The changing roles of both students and teachers mediated by increased student activity and ameliorated by the social interaction through activities raised the level of teacher professional activity in the classrooms. The results of this study show that teachers 
TABLE 4: Change in the use of materials and social context per lesson.

\begin{tabular}{|c|c|c|c|c|}
\hline Teacher & Baseline lesson & Cycle 2 lesson & Cycle 3 lesson & Final lesson \\
\hline \multirow[t]{2}{*}{ A } & $\begin{array}{l}\text { Smart board } \\
\text { Textbooks } \\
\text { Student notebooks } \\
\text { Stationery } \\
\text { Social context: Individual answers to } \\
\text { teacher questions }\end{array}$ & $\begin{array}{l}\text { Chocolates to pack and sort } \\
\text { Worksheets } \\
\text { Stationery } \\
\text { Social context: Pair work, teacher } \\
\text { moving around talking to pairs }\end{array}$ & $\begin{array}{l}\text { Textbooks } \\
\text { Student notebooks } \\
\text { Stationery } \\
\text { Social context: Pair work }\end{array}$ & $\begin{array}{l}\text { Worksheet } \\
\text { Smart board } \\
\text { Stationery } \\
\text { Social context: Pair work, group work, } \\
\text { students reporting back to whole class }\end{array}$ \\
\hline & - & $+M+S$ & $+S$ & $+S$ \\
\hline \multirow[t]{2}{*}{ B } & $\begin{array}{l}\text { White board } \\
\text { Student notebooks } \\
\text { Stationery } \\
\text { Social context: Individual answers to } \\
\text { teacher questions }\end{array}$ & $\begin{array}{l}\text { Chalkboard } \\
\text { Student notebooks } \\
\text { Worksheet } \\
\text { Social context: Individual answers to } \\
\text { teacher questions }\end{array}$ & $\begin{array}{l}\text { Chalkboard } \\
\text { Paper } \\
\text { Stationery } \\
\text { 3D shapes } \\
\text { Toothpicks and jelly sweets } \\
\text { Social context: Students working in } \\
\text { pairs and groups }\end{array}$ & $\begin{array}{l}\text { Chalkboard } \\
\text { Textbook } \\
\text { Paper } \\
\text { Social context: Pair work, teacher moving } \\
\text { between pairs }\end{array}$ \\
\hline & - & - & $+M+S$ & $+S$ \\
\hline \multirow[t]{2}{*}{ c } & $\begin{array}{l}\text { Overhead projector } \\
\text { Worksheet } \\
\text { Stationery } \\
\text { Social context: Whole class } \\
\text { discussion, answering teacher } \\
\text { questions, individual seatwork }\end{array}$ & $\begin{array}{l}\text { Wooden blocks } \\
\text { Overhead projector } \\
\text { Large sheet of paper } \\
\text { Social context: Group work, } \\
\text { reporting back to whole class }\end{array}$ & $\begin{array}{l}\text { Chalkboard } \\
\text { Large sheets of paper Stationery } \\
\text { Social context: Group work, reporting } \\
\text { back to whole class }\end{array}$ & $\begin{array}{l}\text { Modelling problem } \\
\text { Paper } \\
\text { Stationery } \\
\text { Social context: Group work on modelling } \\
\text { problem, reporting back to whole class }\end{array}$ \\
\hline & - & $+M+S$ & $+M+S$ & $+S$ \\
\hline \multirow[t]{2}{*}{ D } & $\begin{array}{l}\text { Overhead projector } \\
\text { Student notebooks } \\
\text { Stationery } \\
\text { Social context: Whole class } \\
\text { discussion, answering teacher } \\
\text { questions, individual seatwork }\end{array}$ & $\begin{array}{l}\text { Textbook } \\
\text { Student notebooks } \\
\text { Stationery } \\
\text { Social context: Whole class } \\
\text { discussion, answering teacher } \\
\text { questions, individual seat work }\end{array}$ & $\begin{array}{l}\text { 3D shapes } \\
\text { School buildings and grounds } \\
\text { Social context: Whole class } \\
\text { discussion, pair work }\end{array}$ & $\begin{array}{l}\text { Word problems on workcard } \\
\text { Student notebooks } \\
\text { Stationery } \\
\text { Social context: Pair work, whole class } \\
\text { discussion }\end{array}$ \\
\hline & - & - & $+M+S$ & $+S$ \\
\hline \multirow[t]{2}{*}{$E$} & $\begin{array}{l}\text { Overhead projector } \\
\text { Student notebooks } \\
\text { Social context: Individual seat work }\end{array}$ & $\begin{array}{l}\text { Chalkboard } \\
\text { Textbook } \\
\text { Student notebooks } \\
\text { Stationery } \\
\text { Social context: Whole class } \\
\text { discussion, individual seatwork }\end{array}$ & $\begin{array}{l}\text { Worksheets with printed pictures } \\
\text { Scissors } \\
\text { Glue } \\
\text { Student notebooks } \\
\text { Stationery } \\
\text { Social context: Individual problem- } \\
\text { solving, whole class discussion }\end{array}$ & $\begin{array}{l}\text { 3D shapes } \\
\text { Cardboard } \\
\text { Rulers, pencils, scissors } \\
\text { Social context: Individual constructions, } \\
\text { whole class discussion }\end{array}$ \\
\hline & - & $+S$ & $+M+S$ & $+\mathrm{M}+\mathrm{S}$ \\
\hline
\end{tabular}

\begin{tabular}{|c|l|l|l|}
\hline & \multicolumn{3}{|c|}{$\longrightarrow$ Inductive } \\
\hline Teacher & Practising a procedure & $\begin{array}{c}\text { Applying a procedure to } \\
\text { a new situation }\end{array}$ & $\begin{array}{c}\text { Inventing new } \\
\text { procedures or analysing } \\
\text { new situations }\end{array}$ \\
\hline A & Lesson 1 & Lesson 2 and 4 & Lesson 3 \\
\hline B & Lesson 1 & Lesson 2 & Lesson 3 and Lesson 4 \\
\hline C & Lesson 1 & Lesson 2 and Lesson 3 & Lesson 4 \\
\hline D & Lesson 1 & Lesson 2 and Lesson 4 & Lesson 3 \\
\hline E & Lesson 1 & Lesson 2 & Lesson 3 and Lesson 4 \\
\hline
\end{tabular}

FIGURE 1: Promotion of inductive reasoning.

incorporated more active learning activities in their own way and with the content that they were required to teach. The results suggest that smaller problem-based activities are the first step in changing activity levels in classrooms while modelling problems were starting to come to the fore at the end of the programme.

Teachers' didactisation practices in the main study showed signs of development through the programme. After careful consideration of each teacher's personal development, the following hierarchy was formulated to show which didactisation practices developed first. As a result of increased student activity, the other practices were made visible to teachers and could evolve and develop. Effective professional development of Mathematics teachers should therefore have a solid base of how and why student activity contributes to both abstract and generalisable thinking in students and changing of teaching practices in teachers. Figure 2 shows the foundational construct that student activity played in this teacher development programme. The hierarchy also shows that the more abstract thinking required by teachers is in the form of generalisations needed for connecting student ideas and vertically aligning lessons. The increasing difficulty in these practices is as a result of abstraction and generalisation on the teacher's part.

\section{Conclusion}

Teacher professional development programmes for both inservice and pre-service teachers would benefit from focusing on the level and conditions of student activity. This formed a cornerstone in this article. Although the professional development programme in the main study focused on all nine didactisation practices, student activity appears to have resonated most with the teachers. It was only once they incorporated student activity into their own teaching in their own ways and to suit their own needs, did the other didactisation practices develop. It also provided teachers with their own experiences to share and build upon. By focusing on increasing student mathematical activity in the classroom teachers were able to mediate the challenge of the changing roles for themselves and their students. An evolution of changing social contexts for the lessons took place. Students were given more responsibility in the latter lessons as they were given different activities to complete. Students were also doing more talking in the latter lessons. It was however found that tying together and connecting different student ideas and integrating different ways of thinking about concepts was still challenging for teachers by the end of the programme (Biccard, 2013, p. 272). This suggests 


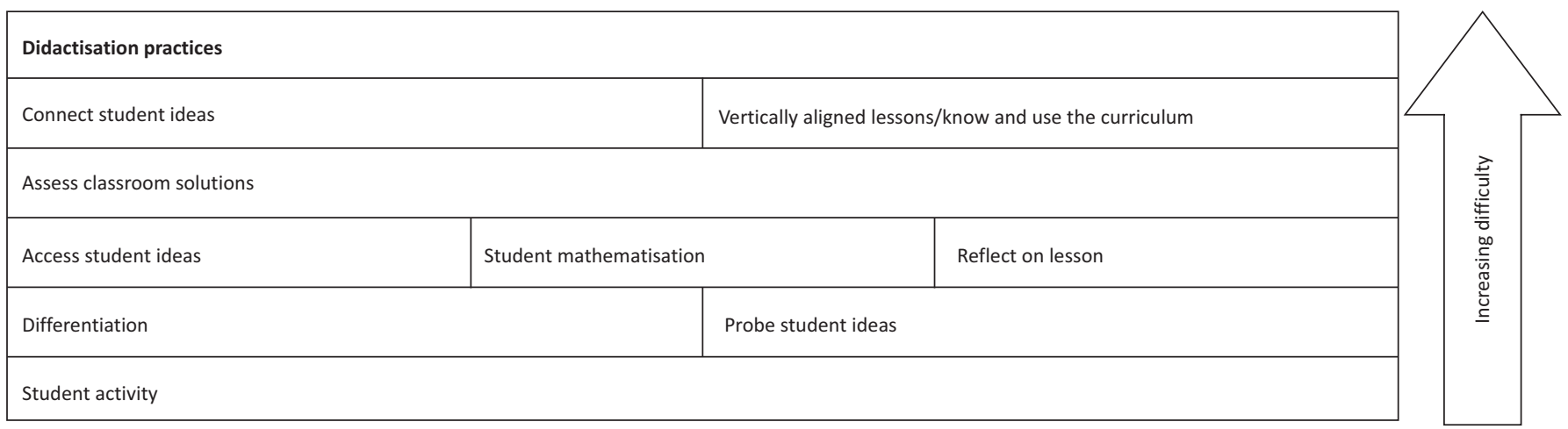

Source: Biccard, P. (2013). The didactisation practices in primary school mathematics teachers through modelling. Unpublished doctoral dissertation. Stellenbosch University, Stellenbosch, South Africa. Available from http://hdl.handle.net/10019.1/85598

FIGURE 2: Didactisation practices hierarchy.

the need for prolonged studies of this nature or studies that focus exclusively on student activity or how teachers can be developed to more skilfully connect student ideas that result from this activity. Student mathematical activity was a key result of the main study. Extending the range and depth of student mathematical activity in classrooms may be pivotal in realising teacher change and improved mathematical performance of students.

\section{Acknowledgements Competing interests}

The authors declare that they have no financial or personal relationships that may have inappropriately influenced them in writing this article.

\section{Authors' contributions}

P.B. (Stellenbosch University) was the researcher for the doctoral study and D.W. (Stellenbosch University) was the promoter for the study. This article was written with consistent input from both authors.

\section{References}

Bakker, A. (2004). Design research in statistics education: On symbolizing and computer tools. Unpublished doctoral dissertation. Centre for Science and Mathematics Education, Utrecht University, The Netherlands. Available from http://dspace. library.uu.nl/handle/1874/893

Biccard, P. (2013). The didactisation practices in primary school mathematics teachers through modelling. Unpublished doctoral dissertation. Stellenbosch University, Stellenbosch, South Africa. Available from http://hdl.handle. net/10019.1/85598

Brousseau, G. (1997). Theory of didactical situations in mathematics. Didactique des mathematiques, 1970-1990. Dordrecht: Kluwer Academic Publishers.

Cobb, P. (2007). Putting philosophy to work: Coping with multiple theoretical perspectives. In F.K. Lester Jr (Ed.), Second handbook of research on mathematics teaching and learning (pp. 3-38). Charlotte, NC: Information Age.

Cobb, P., Confrey, J., diSessa, A., Lehrer, R., \& Schauble, L. (2003). Design experiments in educational research. Educational Researcher, 32(1), 9-13. http://dx.doi. org/10.3102/0013189X032001009

Department of Basic Education. (2013). Report on the annual national assessment of 2013. Available from http://www.education.gov.za/LinkClick.aspx?fileticket=aNm oQzul $2 \% 2 \mathrm{fY} \% 3 \mathrm{~d} \&$ tabid=358\& $\mathrm{mid}=1325$

Fosnot, D.T., Dolk, M., Zolkower, B., Hersch, S., \& Seignoret, H. (2006). Mathematics in the city: Measuring teacher change in facilitating mathematization. Available from http://www.curriculum.org/LNS/coaching/files/pdf/Mathematics_City.pdf
Freudenthal, H. (1991). Revisiting mathematics education. China lectures. Dordrecht: Kluwer Academic Publishers.

Freudenthal, H. (1993). Thoughts on teaching mechanics: Didactical phenomenology of the concept of force. Educational Studies in Mathematics, 25, 71-87. http:// dx.doi.org/10.1007/BF01274103

Gravemeijer, K. (1994). Developing realistic mathematics education. Utrecht: CD-B Press, Freudenthal Institute.

Hmelo-Silver, C. (2004). Problem-based learning: What and how do students learn? Educational Psychology Review, 16(3), 235-266. http://dx.doi.org/10.1023/ B:EDPR.0000034022.16470.f3

Lesh, R., \& Doerr, H. (2003). Foundations of models and modelling perspective. In R. Lesh, \& H.M. Doerr (Eds.), Beyond constructivism: Models and modelling perspectives on mathematics problem solving, learning and teaching (pp. 3-33). Mahwah, NJ: Lawrence Erlbaum Associates Publisher.

McKenney, S., Nieveen, N., \& Van den Akker, J. (2006). Design research from a curriculum perspective. In J.G. van den Akker (Ed.), Educational design research (pp. 67-90). New York, NY: Routledge.

McMillan, J.H., \& Schumacher, S. (2006). Research in education: Evidence-based inquiry. (6th edn.). Boston, MA: Pearson Education Inc.

$\mathrm{Ng}$, K. (2010). Initial experiences of primary school teachers with mathematical modelling. In B. Kaur, \& J. Dindyal (Eds.), Mathematical applications and modelling: Yearbook 2010 (pp. 129-145). Singapore: World Scientific Press. http://dx.doi. org/10.1142/9789814313353_0008

Pea, R.D. (1993). Practices for distributed intelligence and designs for education In G. Salomon (Ed.), Distributed cognitions: Psychological and educational considerations (pp. 47-87). Cambridge: Press Syndicate.

Pegg, J., \& Tall, D. (2005). The fundamental cycle of concept construction underlying various theoretical frameworks. ZDM: The International Journal on Mathematics Education, 37(6), 468-475. http://dx.doi.org/10.1007/BF02655855

Schorr, R.Y., \& Lesh, R. (2003). A modelling approach for proving teacher development In R. Lesh, \& H.M. Doerr (Eds.), Beyond constructivism: Models and modelling perspective on mathematics problem solving, learning and teaching (pp. 141-158). perspective on mathematics problem solving, learning and
Mahwah, NJ: Lawrence Erlbaum Associates Publishers.

Skemp, R. (1986). The psychology of mathematics. Harmondsworth: Penguin.

Stigler, J.W., \& Hiebert, J. (1998). Teaching is a cultural activity. American Educator, 22(4), 1-10.

Stigler, J.W., \& Hiebert, J. (2004). Improving mathematics teaching. Educational Leadership, 61(5), 12-17. Available from http://www.ascd.org/publications/ educational-leadership/feb04/vol61/num05/Improving-Mathematics-Teaching. aspx

Stillman, G. (2010). Implementing applications and modelling in secondary schools: Issues for teaching and learning. In B. Kaur, \& J. Dindyal (Eds.), Mathematical
applications and modelling: Yearbook 2010 (pp. 300-319). Singapore: World applications and modelling: Yearbook 2010 (pp. 300-319). Singap
Scientific Press. http://dx.doi.org/10.1142/9789814313353_0016

Timms, M. (2006). Classroom observation instrument for SPIRIT project. Available from http://tekbot.unl.edu/SPIRITEVAL/summaries/SPIRIT_obs_ins.doc

Treffers, A. (1987). Three dimensions: A model of goal and theory description in mathematics instruction - The Wiskobas Project. Dordrecht: Reidel. http://dx.doi. org/10.1007/978-94-009-3707-9

Vygotsky, L. (1978). Mind in society: The development of highter psychological processes. Cambridge, MA: Harvard University Press.

Walker, D. (2006). Toward productive design studies. In J. Van den Akker, K. Gravemeijer, S. McKenney, \& N. Nieveen (Eds.), Educational design research (pp. 8-14). New York, NY: Routledge.

Wilson, P., \& Heid, M.K. (Eds). (2010). Framework for mathematical proficiency for teaching. Athens, GA: Center for Proficiency in Teaching Mathematics at the Universtiy of Georgia. 